\title{
Research on the Relationship Between Executive Incentive Mode and Enterprise Innovation Ability-Based on Empirical Evidence of Listed High-Tech Companies
}

\author{
Guangqiang Han ${ }^{1, a}$, Xiaofei Tang ${ }^{1, b, ~ * ~}$
}

${ }^{1}$ College of Economics, Binhai Campus, Bohai Ununiversity, Jinzhou City, Liaoning Province, China

ahangq3@126.com, btxf0921@163.com

${ }^{*}$ Corresponding author

Keywords: Equity Incentive, Salary Incentive, Innovation Ability.

\begin{abstract}
Taking listed high-tech companies as research samples, this paper selects data from 2014 to 2018 to explore the relationship between senior executives' incentives and enterprises' innovation ability, and the influence of enterprise equity nature on this relationship. The results show that the adoption of equity incentive to senior executives will promote the innovation ability of enterprises, while the compensation incentive will weaken the relationship between them. The study has certain enlightenment significance for enterprises in formulating incentive policies for executives to improve their innovation ability.
\end{abstract}

\section{Introduction}

High-tech enterprises are highly knowledge-intensive. At the same time, they are the enterprises with the most frequent scientific and technological activities and the most vigorous scientific research and innovation. They are also the backbone of China's innovation ability and economic development that cannot be ignored. From the perspective of the development needs of comprehensive enterprises and the development requirements of high-tech enterprises, the research on the innovation ability of high-tech enterprises has certain theoretical and practical significance. In order to gain a dominant position in the market competition, most of these companies spare no effort to carry out research and development activities of innovative technology, so research and development ability plays an important role in their development. Therefore, this paper focuses on exploring the influence of equity incentive on the innovation ability of enterprises and the degree of such influence.

\section{Literature Review and Research Hypothesis}

Executive incentives can be divided into two types: short-term compensation incentives and long-term equity incentives. But for the actual situation of enterprise management, equity incentive is the most effective incentive for senior executives. Long-term equity incentive is the long-term compensation based on equity, and the incentive for senior executives is related to the future operating conditions of the enterprise. Incentives are used to adjust the interests of senior executives and enterprises, which is consistent with the principles of agency theory, resource theory and management right theory [1]. Zahra et al. (2000) found that the shareholding ratio of senior executives was significantly positively correlated with the technological innovation activities of enterprises. Hellmann and Thiele (2011) used multi-task mathematical model to test the relationship between executive equity incentive and enterprise innovation and found that equity incentive would have a positive impact on enterprise innovation [2]. Chinese scholars qiao junhua et al. (2015) studied strategic emerging industries and concluded that equity incentive is positively correlated with $\mathrm{r} \& \mathrm{~d}$ investment. Meanwhile, zhang junli and other scholars studied the data of a-share listed companies in China in 2013 and found that the proportion of stock options held by senior executives in the shares of enterprises would affect the innovation investment of enterprises [3]. Therefore, this paper proposes the following hypotheses: 
H1: The way in which an enterprise gives equity incentives to senior executives will have a positive impact on the innovation ability of the enterprise.

Giving senior executives a certain salary incentive will reduce the incentive for them to abandon long-term valuable innovation plans in pursuit of short-term business goals. But at the same time, high-earning managers may be overconfident and waste capital expenditure [4]. That would hurt shareholders. Therefore, excessive compensation incentive plan for senior executives will affect the positive correlation between equity incentive and enterprise innovation ability. Based on this, the following hypotheses were proposed:

$\mathrm{H} 2$ : Executive compensation incentive has a positive impact on the innovation ability of enterprises, and at the same time, it will weaken the positive impact of equity incentive on the innovation ability of enterprises.

\section{Research Design}

\subsection{Data Sources}

This paper analyzes the data of listed companies in China's high-tech industry from 2014 to 2018. The collected data are processed as follows: (1) eliminate all ST, *ST companies; (2) eliminate variables missing samples, exceptions and can not calculate the sample enterprise; (3) at the level of $1 \%$ of the data to Winsorize shrink processing. Finally, the data of 92 high-tech listed companies were obtained for five consecutive years. In this paper, stata15 was used to analyze and process the data, and the sample data were all from the database of flush flush and guotai 'an.

\subsection{Variable Design}

Explained variable: proportion of intangible assets. This paper chooses intangible assets to measure the innovation ability of enterprises. The ratio of enterprise operating income to enterprise is used to express enterprise innovation ability for eliminating the influence of enterprise operating conditions; Explanatory variables: equity incentive for executives and managerial compensation incentive. In this paper, the shareholding ratio of top executives is selected to measure the degree of equity incentive of top executives, and the ratio of the average salary of top three executives to the operating income is used to measure the degree of compensation incentive of top executives; Control variables: enterprise size, free cash flow, total return on assets. In order to make the regression results more robust, control variables were introduced. The scale of enterprise will influence the innovation ability of enterprise, and the natural logarithm of total assets is taken to measure the scale of enterprise. Free cash flow can reflect whether the capital invested in innovation ability is sufficient or not, so it should be included in the scope of control variables. In addition, the return on total assets can also reflect the investment return of enterprise assets, so it is also included in the control variable.

Table 1. Variable declaration.

\begin{tabular}{ccc}
\hline Variable Types & Variable Symbol & Instructions \\
\hline $\begin{array}{c}\text { Explained } \\
\text { Variable }\end{array}$ & FIC & Intangible assets/operating income \\
\hline $\begin{array}{c}\text { Explanatory } \\
\text { Variables }\end{array}$ & MSR & number of shares held by executives/total share capital \\
\cline { 2 - 3 } $\begin{array}{c}\text { Control } \\
\text { Variables }\end{array}$ & PAY & revenue of top three executives/operating income \\
\cline { 2 - 3 } & SIZE & Ln (total assets) \\
\hline
\end{tabular}

\subsection{Model Design}

This paper will use panel data model to study the relationship between executive motivation and innovation ability. Panel data model is also known as parallel data. Multiple sections are selected from time series, and sample data composed of sample observation values are selected from all sections at the same time. Therefore, time series data containing the entire cross section is called panel data. Firstly, this paper verifies the influence of executive equity incentive mode on enterprise innovation ability, regresses the variable of executive equity incentive, and then adds salary incentive 
variable on this basis to explore the moderating effect of salary incentive on the relationship between equity incentive and innovation ability. See model one and model two for details.

$$
\begin{aligned}
& F I C_{\text {it }}=\beta_{0}+\beta_{1} M R S_{i t} \beta_{2} S I Z E_{i t}+\beta_{3} C F_{i t}+\beta_{4} R O A_{i t}+\varepsilon_{i t} \\
& F I C_{\mathrm{it}}=\alpha_{0}+\alpha_{1} M R S_{i t}+\alpha_{2} P A Y_{i t}+\alpha_{3} M R S_{i t} * P A Y_{i t} \\
& +\alpha_{4} S I Z E_{i t}+\alpha_{5} C F_{i t}+\alpha_{6} R O A_{i t}+\varepsilon_{i t}
\end{aligned}
$$

\section{Empirical Analysis}

\subsection{Descriptive Statistics}

This paper conducts descriptive statistics on 460 samples from 92 companies for five consecutive years, and the analysis results are shown in table two. At the same time, the natural logarithm of the continuous variable is taken for analysis. The free cash flow of the enterprise is negative, so the logarithm transformation is not carried out. The standard deviation of executive stock ownership is 0.1653. Compared with the executive compensation level, the executive stock ownership level of different companies is quite different, but the difference in executive compensation level is not obvious.

Table 2. Descriptive Dtatistics of Variables.

\begin{tabular}{ccccc}
\hline Variable & Mean Value & Standard Deviation & Minimum Value & Maximum Value \\
\hline FIC & 0.0924 & 0.0809 & 0.0018 & 0.5037 \\
\hline MSR & 0.0964 & 0.1653 & 0.0000 & 0.8568 \\
\hline PAY & 0.0009 & 0.0009 & 0.0000 & 0.0058 \\
\hline SIZE & 23.2600 & 1.1878 & 20.4277 & 26.6506 \\
\hline CF & $5.87 \mathrm{e}+07$ & $4.28 \mathrm{e}+09$ & $-4.72 \mathrm{e}+10$ & $2.45 \mathrm{e}+10$ \\
\hline ROA & 0.0665 & 0.0754 & -0.8142 & 0.3145 \\
\hline
\end{tabular}

\subsection{Analysis of Empirical Results}

Firstly, a regression analysis is made on the relationship between the equity incentive mode of senior executives and the innovation ability of enterprises, and then the regression of executive compensation incentive is added to observe the change of the result. In this paper, fixed effect regression and random effect regression suitable for panel data regression are adopted. Then Hausman test is used to determine more applicable regression results, and the most appropriate method is selected for analysis. The analysis results are shown in table three.

Table 3. Model 1 Mixed Regression, Random Effect Regression and Fixed Effect regression Results.

\begin{tabular}{cccc}
\hline & ols & RE & FE \\
\hline \multirow{2}{*}{ MSR } & $0.0772^{*}$ & 0.0600 & $0.0676^{* *}$ \\
& $(0.0418)$ & $(0.0444)$ & $(0.0330)$ \\
\hline \multirow{2}{*}{ SIZE } & $-8.03 \mathrm{e}-05$ & 0.00265 & 0.00172 \\
& $(0.00547)$ & $(0.00504)$ & $(0.00411)$ \\
\hline \multirow{2}{*}{ CF } & $0 * *$ & 0 & 0 \\
& $(0)$ & $(0)$ & $(0)$ \\
\hline \multirow{2}{*}{ ROA } & $-0.204^{*}$ & $-0.0718^{* *}$ & $\left(0.0866^{* * *}\right.$ \\
& $(0.104)$ & $(0.0330)$ & $(0.0323)$ \\
\hline Observations & 460 & 460 & 460 \\
\hline R-squared & 0.057 & 0.017 & 0.017 \\
\hline
\end{tabular}

Note: standard error in brackets, $*, * *$ and $* * *$ indicate significant levels of $10 \%, 5 \%$ and $1 \%$, respectively.

The $\mathrm{p}$ value tested by Hausman in the model is greater than zero 0.01 , so the results of model one are analyzed by using random effects. The coefficient of equity incentive variable of senior executives is positive, which indicates that equity incentive can effectively promote senior executives' attention to innovation activities to some extent, so as to improve the innovation ability of 
enterprises, which is significant at the level of five per cent. At the same time, it is found through observation that the control variables such as enterprise size and free cash flow can all pass the significance test and play an effective auxiliary role in the regression results of the equation.

Table 4. Model 2 Mixed Regression, Random Effect Regression and Fixed Effect regression Results.

\begin{tabular}{|c|c|c|c|}
\hline & ols & $\mathrm{RE}$ & $\mathrm{FE}$ \\
\hline \multirow{2}{*}{ MSR } & $0.0706 *$ & 0.0553 & $0.0612 *$ \\
\hline & $(0.0392)$ & $(0.0416)$ & $(0.0314)$ \\
\hline \multirow{2}{*}{ PAY } & $29.01 * *$ & $32.62 * * *$ & $32.10 * * *$ \\
\hline & (11.69) & $(4.515)$ & $(4.166)$ \\
\hline \multirow{2}{*}{ SIZE } & $0.0143^{* *}$ & $0.0170 * * *$ & $0.0165 * * *$ \\
\hline & $(0.00587)$ & $(0.00512)$ & $(0.00433)$ \\
\hline \multirow{2}{*}{$\mathrm{CF}$} & $0 * * *$ & 0 & 0 \\
\hline & $(0)$ & $(0)$ & $(0)$ \\
\hline \multirow{2}{*}{ ROA } & -0.142 & -0.0473 & $-0.0567 *$ \\
\hline & $(0.0862)$ & $(0.0311)$ & $(0.0305)$ \\
\hline Observations & 460 & 460 & 460 \\
\hline R-squared & 0.131 & 0.017 & 0.14 \\
\hline
\end{tabular}

Note: standard error in brackets, $*, * *$ and $* * *$ indicate significant levels of $10 \%, 5 \%$ and $1 \%$, respectively.

On the basis of the research on the model, the model puts forward the cross item between equity incentive and salary incentive to test the effect of salary incentive on innovation ability and explore the moderating effect. Hausman test results show that the stochastic model works better. The results show that the regression coefficients of executive equity incentive and executive compensation incentive are both positive and significant at the level of one per cent and five per cent respectively, indicating that both of the two incentive modes have a positive impact on the innovation ability of enterprises. Hypothesis one is verified. At the same time, the significant level of equity incentive decreased from five per cent to one per cent, which indicates to some extent that compensation incentive has a negative regulating effect on the impact of equity incentive on the innovation ability of enterprises. When an enterprise pays a high short-term salary to senior executives, it will weaken their expectation of long-term incentive and reduce the incentive effectiveness of equity incentive. On the basis of immediate compensation, senior executives are inert to risky innovation. Therefore, hypothesis two is verified.

\section{Conclusions and Recommendations}

Based on the analysis of the data of 92 Chinese high-tech listed companies from 2014 to 2018, the empirical results show that: there is a positive correlation between executive stock ownership and enterprise innovation ability, and executive compensation incentive can also promote enterprise innovation ability, but it also has a negative impact on the relationship between executive equity incentive and enterprise innovation ability.

By studying the relationship between incentive mode and enterprise innovation ability, this paper can promote enterprises to formulate incentive schemes more effectively so as to improve their innovation ability. Therefore, the following Suggestions are proposed:

(1) The enterprise can motivate senior executives to work actively and enhance their sense of happiness through equity incentives, so as to enhance the competitiveness of the enterprise. Equity incentive can form an interest alliance between senior executives and enterprises, and to reduce senior executives' concerns about the uncertain benefits generated by enterprise innovation activities, so that senior executives can make reasonable judgments from the perspective of the long-term development of enterprises.

(2) When making incentive plans, enterprises should consider the different effects of equity incentive and salary incentive. Although equity incentive and compensation incentive are both effective incentives for senior executives, excessive compensation incentive will lead to short-sighted 
behavior of senior executives and deviation in decision-making. Therefore, it is necessary to weigh the advantages and disadvantages of the incentive plan for executives and consider it comprehensively from the actual situation of the enterprise.

\section{References}

[1] Bebchuk L A, Fried J M. Executive Compensation at Fannie Mae: A Case Study of Perverse Incentives, Nonperformance Pay, and Camouflage. Journal of Corporation Law, vol.4, 2005.

[2] Hellmann T, Thiele V. Incentives and Innovation: A Multitasking Approach. American Economic Journal Microeconomics, vol.1, pp. 78-128, 2011.

[3] Zhang Junli,J in Hao, Li Guodong. Research on the driving factors of corporate governance in technological innovation of enterprises. Modern Management Science, vol.10, pp. 106-108, 2015.

[4] Lu Tong, Dang Yin. Corporate governance and technological innovation: sector comparison. Economic Research Journal, vol.6, pp. 115-128, 2014. 